\title{
CLINICAL AND HISTOPATHOLOGICAL EVALUATION OF USING PLATELET-RICH PLASMA AND PLATELET-RICH FIBRIN MATRIX IN TREATMENT OF INDUCED CHRONIC OPEN WOUNDS IN BUCKS
}

\author{
FALAH H KHALAF ${ }^{1 *}$, SERWA IBRAHIM SALIH ${ }^{2}$ \\ ${ }^{1}$ Department of Surgery and Obstetrics, College of Veterinary Medicine, University of Diyala, Baqubah, Iraq. ${ }^{2}$ Department of Surgery and
} Obstetrics, College of Veterinary Medicine, University of Baghdad, Baqubah, Iraq. Email: fhkhlaf@gmail.com

Received: 04 December 2017, Revised and Accepted: 12 February 2018

\begin{abstract}
Objective: This study was designed to identify the effectiveness of platelet-rich plasma gel (PRP) and platelet-rich fibrin matrix (PRF) application on the induced open chronic full-thickness cutaneous wounds in goats.

Methods: A total of 24 adult apparently healthy local breed bucks were used in this study. PRP gel and PRF matrix were prepared from whole blood at the time of treatment, four square full-thickness skin wounds $(4 \mathrm{~cm} \times 4 \mathrm{~cm})$ on the dorsal sides of the back of each animal were created, by daily scratched to interrupt healing process continuation to prolong inflammatory reaction to form chronic wound, this surgical procedure was continued for 8 weeks to ensure the traditional chronicity wounds, after that they were treated by PRP gel in the first group (n=12), while PRF matrix was used in the second group $(n=12)$. Each group was also subdivided into treatment ( $n=2$ wounds) and control group ( $n=2$ wounds) in each animal. The healing process was evaluated by clinical examination during experimental period and histologically in day 7, 14, 28, and 45 post operation.
\end{abstract}

Conclusion: Both groups showed faster tissue repair and epithelialization in treatment groups compared to control groups. The results of this study confirmed PRP gel and PRF matrix application improved and accelerated cutaneous open chronic wound healing.

Keyword: Wound healing, Chronic wound, Platelet-rich plasma gel, Platelet-rich fibrin matrix, Bucks.

(C) 2018 The Authors. Published by Innovare Academic Sciences Pvt Ltd. This is an open access article under the CC BY license (http://creativecommons. org/licenses/by/4. 0/) DOI: http://dx.doi.org/10.22159/ajpcr.2018.v11i5.24105

\section{INTRODUCTION}

A wound is defined as damage or disruption to the normal anatomical structure and function of tissues [1]. Chronic wounds are defined as wounds that fail to proceed through the normal phases of wound healing in an orderly and timely manner. Often, chronic wounds stay in the inflammation phase of healing [2]. Wound healing, a natural restorative response to tissue injury, is governed by an elaborate response driven by resident and circulating cells, homing to the injury site that releases soluble mediators or signals generated from the extracellular matrix [3]. The wound healing process consists of four highly integrated and overlapping phases: Hemostasis, inflammation, proliferation, and tissue remodeling. These phases and their biophysiological functions must occur in the proper sequence, at a specific time and continue for a specific duration at an optimal intensity [4].

Platelets have importantsecretory functions, express internal membrane proteins, and release adhesive proteins, coagulation, and growth factors; platelets play an important role in inflammatory and proliferative events and play a critical role for tissue remodeling and wound healing [5]. Platelet-rich plasma (PRP) is a portion of the plasma fraction that has a platelet concentration above baseline values [6]. PRP works by secretion of growth factors following platelet activation and released growth factors bind to the external surface of cell membranes in applied tissue. Activation of platelets in PRP induces the release of several growth factors that are stored in $\alpha$-granules such as platelet-derived growth factor (PDGF), transforming growth factor- $\beta$ (TGF- $\beta$ ), insulinlike growth factor (IGF), vascular endothelial growth factor (VEGF), fibroblast growth factor (FGF), and epidermal growth factor (EGF) [7]. PRP with its high-level growth factor contents is used clinically for bone and wound healing, oral maxillofacial surgery, dental surgery, and plastic surgery [6]. PRP works by secretion of growth factors following platelet activation and released growth factors bind to the external surface of cell membranes in applied tissue $[5,6]$. Uses of PRP in animals are steadily increasing, and its effects on tissue healing have been reported in many studies, particularly in bone regeneration and ligament or tendon reconstruction. Some studies have also described its healing effects in cutaneous wounds in horses, dogs, goats, and others animals species [8-13]

Platelet-rich fibrin (PRF) is classified as the second generation platelet derivative, unlike PRP; PRF is a strictly autologous fibrin matrix containing a large quantity of platelets and leukocytes. Its preparation technique does not require artificial or exogenous biochemical modifications such as the use of anticoagulants or bovine thrombin or any other jellifying agent [14]. PRF clot is obtained by inducing a natural polymerization process during centrifugation without the addition of anticoagulants, and due to this, the obtained fibrin clot has a very dense fibrin network in which platelets and leukocytes are entrapped and activated in a natural mechanism, thus releasing growth factors and cytokines in a slow rate during a period of 7 days or more [15].

\section{METHODS}

Animals

A total of 24 adult apparently healthy local breed bucks were used. Weighted 25-35 kg and aged 2-3 years, they were examined physically and clinically, all animals were housed under similar management conditions and feeding.

\section{Preparation of PRP}

The blood was drawn from the jugular vein carefully into syringe $(18 \mathrm{~mL})$ containing $2 \mathrm{~mL} \mathrm{3.8 \%} \mathrm{sodium} \mathrm{citrate} \mathrm{as} \mathrm{anticoagulant} \mathrm{[16]} \mathrm{divided}$ into two tubes of $10 \mathrm{~mL}$ and centrifuged (Electric centrifuge, China) at $2800 \mathrm{rpm}$ for $15 \mathrm{~min}$. This procedure divides the blood into three basic components: Red blood cells (RBCs) at the bottom, PRP in the middle, and platelet poor plasma (PPP) at the top. RBCs were isolated from the overlying buffy coat and plasma by the gel-like plug within the tubes. 
From each tube ( $9 \mathrm{~mL}$ of blood) yielded approximately $4-5 \mathrm{~mL}$ of PPP. The buffy coat of each tube, contained mononuclear cells and platelets, The final solution, that obtained by mixing different buffy coats in a sterile $10 \mathrm{ml}$ tube, was second centrifuged at $2800 \mathrm{rpm}$ for $15 \mathrm{~min}$ for good separation of platelets in two layers with platelet in the supernatant layer. The platelet accumulates at the bottom of the tube, the PPP on top. The PPP is drawn off so that the PRP remains in the tube; the final PRP was obtained approximately $1 \mathrm{~mL}$ drawn up with an insulin syringe into Petri dish and platelets were activated by adding $0.2 \mathrm{~mL}$ of $10 \%$ calcium chloride to form PRP gel which was used in the wounded area [17].

\section{Preparation of PRF matrix}

The protocol for PRF preparation includes collection of whole venous blood $(10 \mathrm{~mL})$ in each of the two sterile tubes $(10 \mathrm{~mL})$ without anticoagulant and the tubes immediately were placed in a centrifugal machine at $3000 \mathrm{rpm}$ for $10 \mathrm{~min}$, after which it settles into the following three layers: Upper straw-colored a cellular plasma, red-colored lower fraction containing RBCs, and the middle fraction containing the fibrin clot. The upper straw-colored layer was removed and middle fraction was collected which was PRF. A fibrin clot is then formed in the middle between the RBCs at bottom and a cellular plasma at the top. The middle part is platelets trapped massively in fibrin meshes. The fibrin clot then withdrawn up with thumbs' forceps from tube and cutting off the RBC that adhered to it; the clot was squeezed between two sterile gauge pieces to obtain autologous fibrin membrane $[18,19]$.
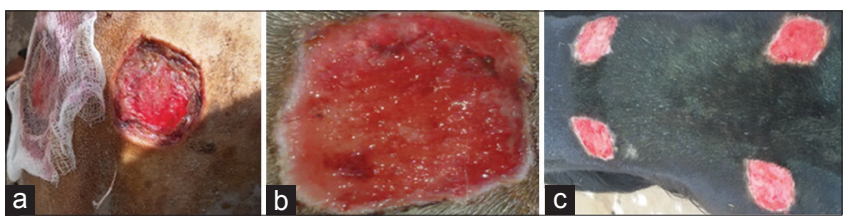

Fig. 1: (a-c) Chronic wounds induction through the $2^{\text {nd }}$ week and 8 weeks (b)
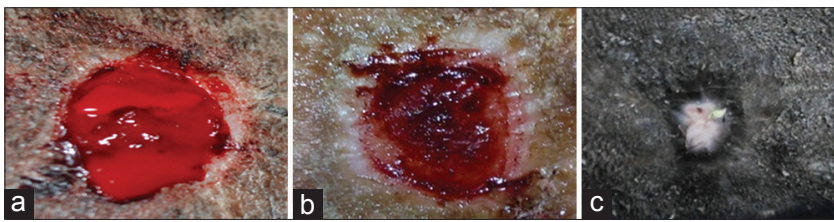

Fig. 2: (a-c) Platelet-rich plasma at the time and after treatment

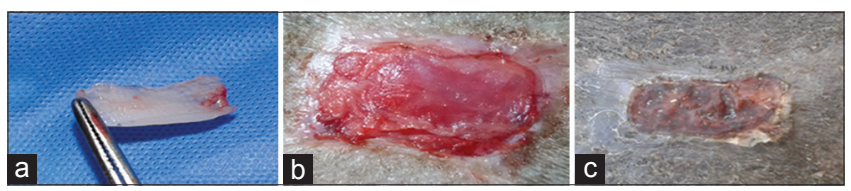

Fig. 3: (a-c) Platelet-rich fibrin membrane at the time of treatment and after 1 week

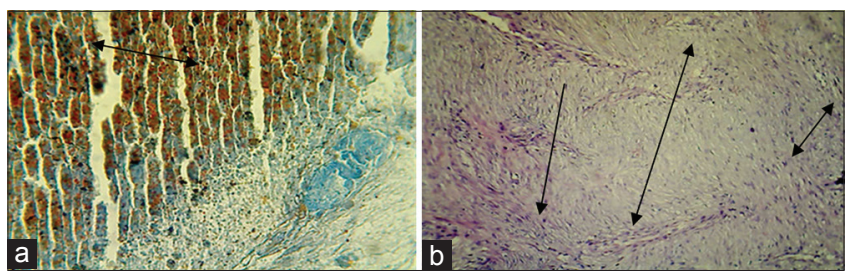

Fig. 4: ( $a$ and b) Histopathological section in the skin at 8 weeks postwound shows hemorrhage in the epidermis in the first section and immature granulation tissue in the incision characterized by few blood vessels regular few cellular collagen fiber and few mononuclear cells around blood vessels in the second section ( $H$ and $E$ stain $\times 100$ )
Surgical procedure

Food was withdrawn for $24 \mathrm{~h}$ and water restricted $12 \mathrm{~h}$ before surgery. The animals were controlled in standing position with light sedation using xylazine hydrochloride (Xyla-MD, Germany) in dose of $0.2 \mathrm{mg} / \mathrm{kg}$ b.w. I.M and local anesthesia using inverted $\mathrm{L}$ technique in wound borders with lidocaine hydrochloride (lido 2\%, India) [20], skin and subcutaneous tissues were removed to make four square full-thickness skin wounds $(4 \mathrm{~cm} \times 4 \mathrm{~cm})$ on the dorsal sides of the back of each animal (two wounds on each side), $10 \mathrm{~cm}$ apart after preparation of the area in routine surgical manner one for treatment group and second as control group.

Under effect of local anesthetic using lidocaine hydrochloride spray $10 \%$ (lidocaine hydrochloride, Media, Syria), the wounds were daily scratched to interrupt healing process continuation to prolong inflammatory reaction to form chronic wound, this surgical procedure was continued for 8 weeks to ensure the chronicity [21], then the wounds treated using PRP in the first group (12 animals) and PRF for the second group (12 animals) which were prepared as previously described directly at time of treatment in 1-week interval.

\section{Clinical evaluation}

Physiological parameters exemplified body temperature, heart rate, respiration, and appetite were evaluation after inducing wounds and every day of treatment. Wounds were checked for evaluated such as swelling, inflammation, and infection during induction of chronic wounds and after treatment.

\section{Histopathological evaluation}

Biopsies were taken from edges and periphery of wounds and kept in $10 \%$ buffer formalin solution for histopathological study in the period

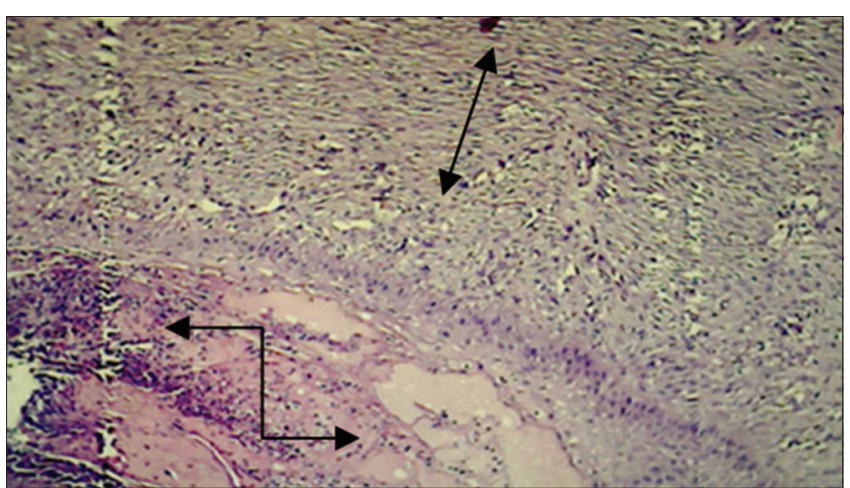

Fig. 5: Histopathological section in the skin at 7 days postwound treatmented by platelet-rich plasma shows thickness in epithelial cells layer extended over granulation tissue and under cellular debris (H and $E$ stain $\times 100)$

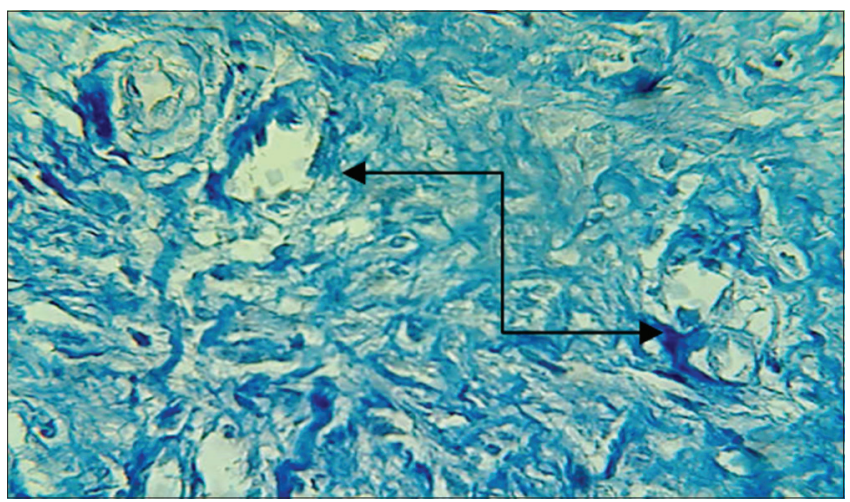

Fig. 6: Histopathological section in the skin at 7 days postwound treatmented by platelet-rich plasma shows deep blue color mature granulation tissue in the incision site (Mallory's trichrome stain $\times 400$ ) 


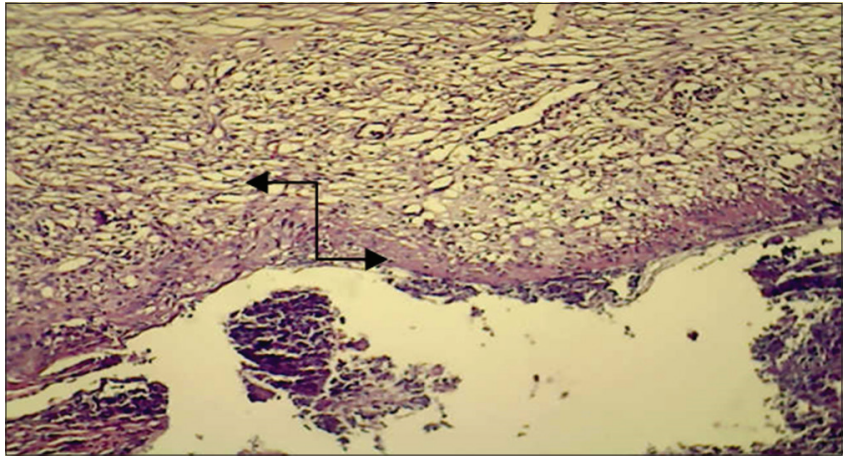

Fig. 7: Histopathological section in the skin at 7 days post operation in control of treatment by platelet-rich plasma shows thin layer of epithelial cells extended under cellular debris and over immature granulation tissue characterized by irregular cellular collagen fiber with numerous blood vessels as well as mononuclear cells infiltration ( $\mathrm{H}$ and $\mathrm{E}$ stain $\times 100$ )

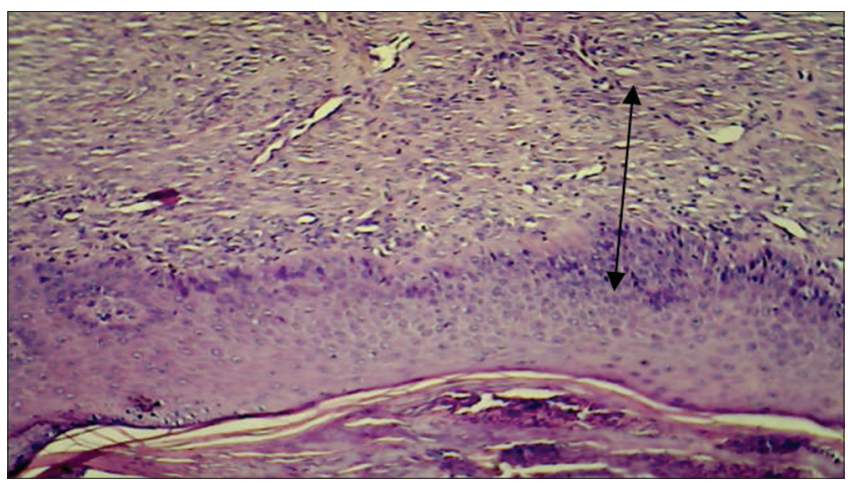

Fig. 8: Histopathological section in the skin at 14 days postwound treatmented by platelet-rich plasma shows thickness of epidermal layer over mature granulation layer ( $H$ and $E$ stain $\times 100$ )

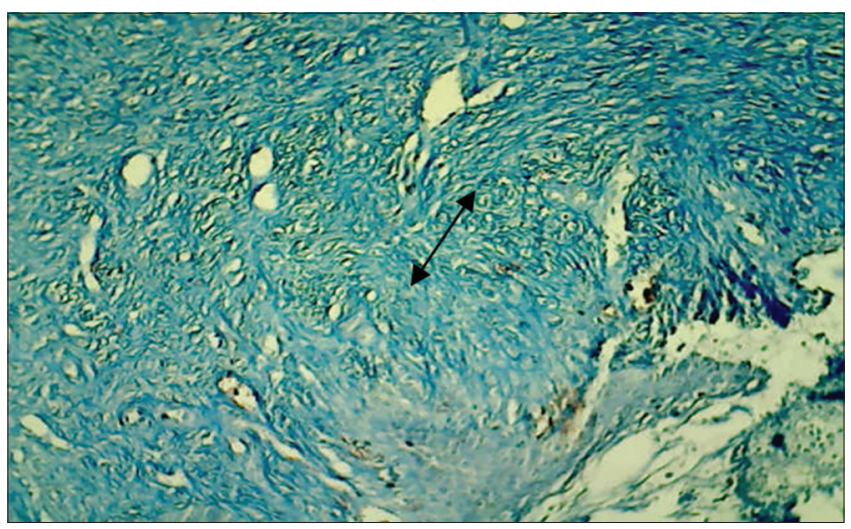

Fig. 9: Histopathological section in the skin at 14 days postwound treatmented by platelet-rich fibrin shows deep blue stain collagen fiber in the incision site (Mallory's trichrome stain $\times 400$ )

of $7,14,28$, and 45 days postoperatively; then, these sections were processed for hematoxylin-eosin and Mallory's trichrome stains to observe the healing prominence of wounded area.

\section{RESULTS AND DISCUSSIONS}

Clinical evaluation

In this study, both PRP gel and autologous of PRF matrix in the treatment of induced open chronic cutaneous wounds in bucks were used.

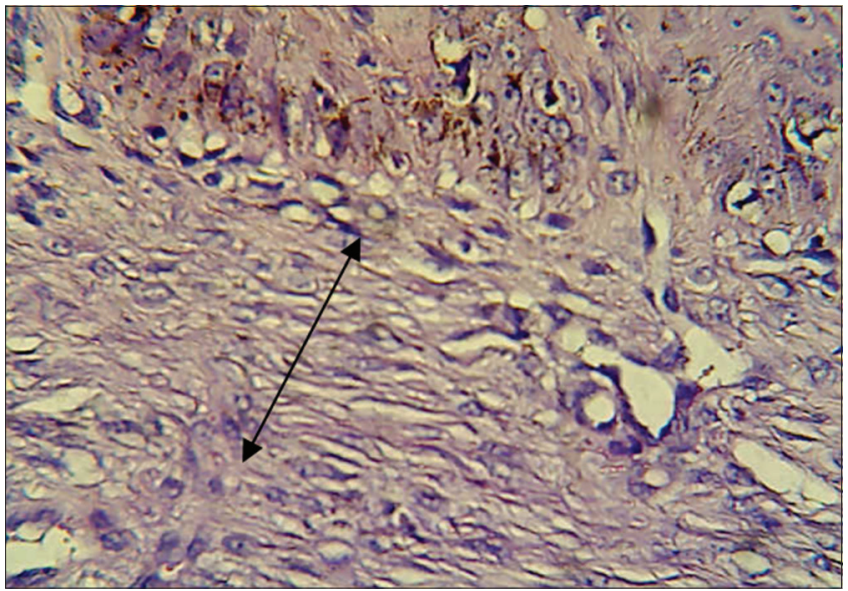

Fig. 10: Histopathological section in the skin at 28 days postwound treatmented by platelet-rich plasma shows complete layer of epidermis over mature granulation tissue $(\mathrm{H}$ and $\mathrm{E}$ stain $\times 400)$

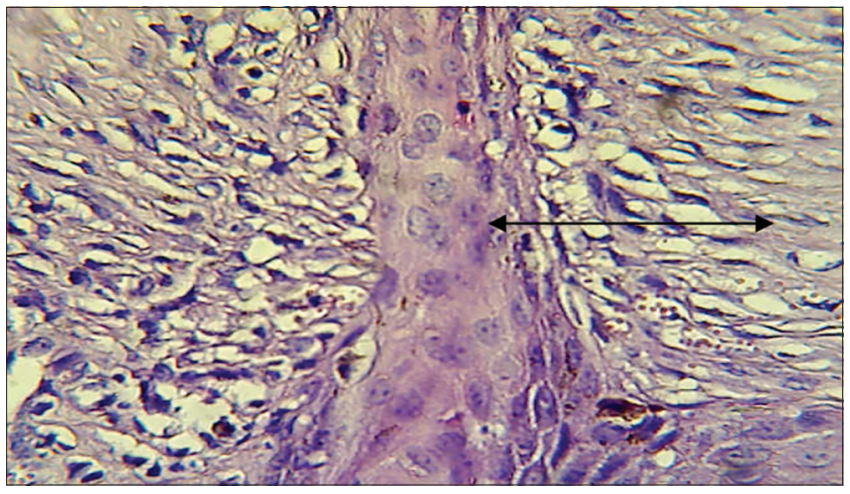

Fig. 11: Histopathological section in the skin at 28 days postwound treated by platelet-rich fibrin shows complete layer of epidermis with rete ridge over mature granulation tissue ( $\mathrm{H}$ and $\mathrm{E}$ stain $\times \mathbf{4 0 0 )}$

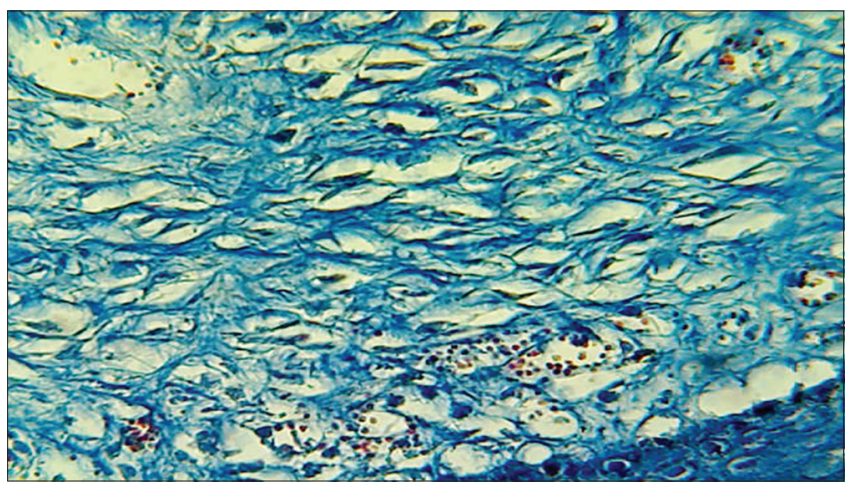

Fig. 12: Histopathological section in the skin at 45 days postwound treated by platelet-rich plasma shows thickness of epidermal layer over blue stain dense collagen fiber (Mallory's trichrome stain $\times 400$ )

Clinical findings of the present study can be put into two categories as follows:

1. Period of inducing wounds: This period started from time of induced surgical wounds and left for 8 weeks with daily mechanical irritation to become chronic as referred by searchers which they refer to time of chronic wound such as Izadi and Ganchi and Reghini et al. [21,22] who revealed that the chronic wound take 6 weeks or more in repair process which reflects chronic state of healing. 


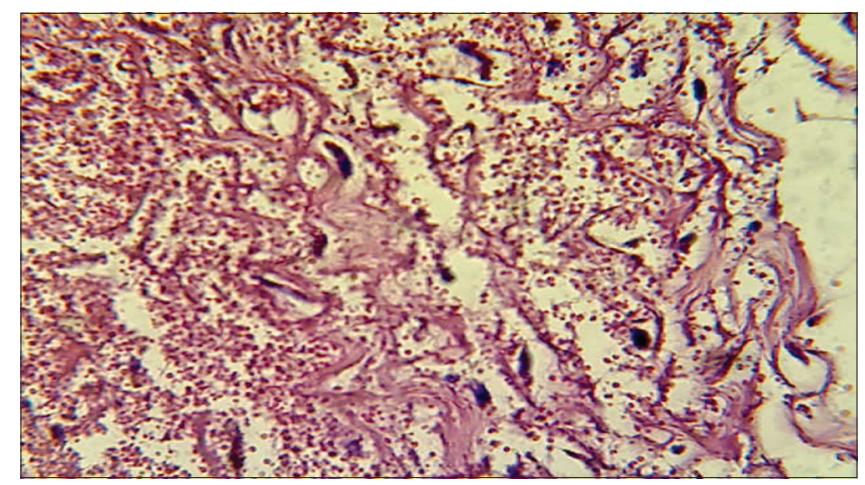

Fig. 13: Histopathological section in the skin at 45 days postwound treated by platelet-rich fibrin shows complete thickness of epidermal layer over dense collagen fiber ( $\mathrm{H}$ and $\mathrm{E}$ stain $\times \mathbf{4 0 0}$ )

Clinical follow-up in the period of induced chronic open wound showed, inflammatory signs in wounded area with systemic reaction, characterized by anorexia, depression and lethargy in the first three days post operation, disappeared gradually within first 3 days to become within normal values. While local inflammatory reaction persisted and were graded from slight to moderate inflammatory swelling with bloody clots formation, inflammatory exudate without signs of infection in all animals during this period except one case, which had scanty pus formation in one wound appeared in the first 3 days post operation, which was treated locally with povidone iodine $10 \%$ for 5 days and systemic antibiotic (20 mg/kg B.W. oxytetracycline).

2. Period of treatment: A complete clinical examination was performed on all animals daily during the treatment periods, the clinical finding showed no infection and all wounds continued on healing process without signs of complications in all animals. In both treated groups, the physiological parameters were in normal values (body temperature, appetite, heart, and respiratory rate) during study period, this result agrees with Kim et al. and Reghini et al. [9,23]. This result of two groups demonstrated that applying PRP and PRF matrix to chronic wound resulted in a significant healing effect, which may be related to platelets role in wound healing in hemostasis and initiation of wound healing, after platelet activation and clot formation, growth factors are released from $\alpha$-granules including PDGF, bTGF-b, VEGF, FGF, IGF, and EGF and bioactive factors such as serotonin, histamine, dopamine, calcium, and adenosine are also stored in these dense granules these growth factors work as biologic mediators to promote cellular activity by binding to specific cell surface receptors [24,25]. DeRossi et al., 2009, who referred to the use of PRP gel in non-healing wounds in equine and in immunocompromised, diabetic or elderly individuals could provide quality healing of acute wounds [10], and Ferdousy et al., 2013, who revealed to the uses of PRP gel for the treatment of cutaneous wounds shown excellent results of healing in goat with skin wounds, and [26] Alishahi et al., 2013, demonstrated that PRF accelerated incisional wound healing in canine [27].

\section{Histopathological evaluation}

\section{Inducing open wound}

The histopathological examination of these group at 8 weeks showed hemorrhage in the epidermis, irregular few cellular collagen fibers, mononuclear cells around blood vessels in the wound, it also showed immature granulation tissue in the incision (H\& E stain 100X).

\section{PRP group}

The microscopical study at 7 days postincision treated with PRP showed thickened layer of epithelial cells extended over granulation tissue and under cellular debris with mature granulation tissue in the incision, deep blue color mature granulation tissue in the incision site with Mallory's trichrome stain, while the histological examination of control group of PRP at 7 days of treatment showed thin layer of epithelial cells extended under cellular debris and over immature granulation tissue characterized by irregular cellular collagen fiber with numerous blood vessels as well as mononuclear cells infiltration.

On day 14, post-treatment of PRP showed complete epidermal layer over mature granulation layer and under cellular debris, dense thickness mature granulation tissue in the incision site ( $\mathrm{H}$ and $\mathrm{E}$ stain), and deep blue color of mature granulation tissue in other section (Mallory's trichrome stain $\times 400$ ). In control group at 14 days after treatment with PRP showed mature granulation with moderate mononuclear cells aggregation around blood vessels ( $\mathrm{H}$ and E stain $\times 100$ ), other section showed neutrophils and mononuclear cells infiltration in the mature granulation tissue in the incision ( $\mathrm{H}$ and $\mathrm{E}$ stain)

On day $28^{\text {th }}$ of treatment, histopathological evaluation was characterized by complete layer of epidermis over mature granulation tissue $(\mathrm{H}$ and E stain), and very dense blue color collagen fibers (Mallory's trichrome stain), other section showed complete layer of epidermis with rete ridge over mature granulation tissue ( $\mathrm{H}$ and $\mathrm{E}$ stain). The control group at this time showed mature granulation tissue in the wound site $(\mathrm{H}$ and $\mathrm{E}$ stain $\times 400$ ). Few mononuclear cells infiltration in the wall of blood vessels.

On day 45, the histopathological section showed complete thickness of epidermal layer over dense collagen fiber (H and $\mathrm{E}$ stain) and blue color of dense collagen fiber on special stain. In control group, there was dense collagen fibers in the wound site with mononuclear cells aggregation around blood vessels in the dermal layer.

\section{PRF matrix}

The histopathological evaluation of PRF group on $7^{\text {th }}$ day of treatment showed thick layer of epithelial cells extended over granulation tissue and under cellular debris infiltrated by few mononuclear cells $(\mathrm{H}$ and E stain), another section showed granulation tissue in the dermis with complete epidermal layer and showed deep blue color collagen fiber with Mallory's trichrome stain. In control group of PRF on day seven showed moderate mononuclear cells aggregation around blood vessels, and another section showed mononuclear cells infiltration in the immature granulation tissue in the wound.

On day 14 post treatment showed thickned layer of epithelial cells extended over granulation tissue and under cellular debris infiltrated by few mononuclear (H\& E stain) (Fig. 4.25). Another section also showed dense thick mature granulation tissue (H\& E stain ) and on the special stain appeared as deep blue stained collagen fibers in the wound site.

On day 28 post-treatment, there was a complete layer of epidermis over mature granulation tissue and in the other section showed complete layer of epidermis with rete ridge over mature granulation tissue $(\mathrm{H}$ and E stain $\times 400$ ) and deep blue color collagen fiber (Mallory's trichrome stain $\times 400$ ). Control group showed mononuclear cells aggregation around blood vessels in the dermal layer $(\mathrm{H}$ and E stain $\times 400)$.

On 45 day postincision, there was showed complete thickness of epidermal layer over dense collagen fiber $(\mathrm{H}$ and $\mathrm{E}$ stain $\times 400)$ and in special stain appeared blue color of collagen fiber and in control group showed dense collagen fiber with mononuclear cells aggregation around blood vessels in the dermal layer $(\mathrm{H}$ and $\mathrm{E}$ stain $\times 400)$.

The histopathological evaluation of this study of PRP and PRF matrix in both control and treatment groups revealed that chronic wound healing process was superior with clear of inflammatory reaction in treatment group. This may be due to both PRP and PRF matrix ability of enhancing wound healing process and high contains of growth factors and activation of these factors such as release of VEGF a mediator of angiogenesis that stimulates endothelial cell proliferation. PDGF also stimulates the production of fibronectin, a cell adhesion molecule used in cellular proliferation and migration during wound healing; these results are supported by other studies revealed the effect of PRP and 
PRF on acute and chronic wound healing and tissue repair in different animals' species and human medical studies [28-31].

\section{CONCLUSION}

The use of PRP gel and PRF matrix as improved therapy for open chronic or non-healing wounds accelerates epithelialization and scar formation; this study demonstrates the beneficial effect of both PRP and PRF as a biological wound healing enhancer.

\section{REFERENCES}

1. Robson MC, Steed DL, Franz MG. Wound healing: Biologic features and approaches to maximize healing trajectories. Curr Probl Surg 2001;38:72-140.

2. Frykberg GR, Banks JB. Advances challenges in the treatment of chronic wounds. Wound Care 2015;4:560-82.

3. Guo S, Dipietro LA. Factors affecting wound healing. J Dent Res 2010;89:219-29.

4. Lodhi, S, Vadnere GP. Relevance and perspectives of experimental wound models in wound healing research. Asian J Pharm Clin Res 2017; 10:57-62.

5. Brissett AE, Hom DB. The effects of tissue sealants, platelet gels, and growth factors on wound healing. Curr Opin Otolaryngol Head Neck Surg 2003;11:245-50.

6. Sun CK, Zhen YY, Leu S, Tsai TH, Chang LT, Sheu JJ, et al. Direct implantation versus platelet-rich fibrin-embedded adipose-derived mesenchymal stem cells in treating rat acute myocardial infarction. Int J Cardiol 2014;173:410-23

7. de Mos M, van der Windt AE, Jahr H, van Schie HT, Weinans H, Verhaar JA, et al. Can platelet-rich plasma enhance tendon repair? A cell culture study. Am J Sports Med 2008;36:1171-8.

8. Jee CH, Eom NY, Jang HM, Jung HW, Choi ES, Won JH, et al. Effect of autologous platelet-rich plasma application on cutaneous wound healing in dogs. J Vet Sci 2016;17:79-87.

9. Kim JH, Park C, Park HM. Curative effect of autologous platelet-rich plasma on a large cutaneous lesion in a dog. Vet Dermatol 2009;20:123-6.

10. DeRossi R, Coelho AC, Mello GS, Frazílio FO, Leal CR, Facco GG, et al. Effects of platelet-rich plasma gel on skin healing in surgical wound in horses. Acta Cir Bras 2009;24:276-81.

11. Sardari K, Emami MR, Kazemi H, Movasagi AR, Goli AA, Lotfi A, et al. Effects of platelet-rich plasma (PRP) on cutaneous regeneration and wound healing in dogs treated with dexamethasone. Comp Clin Pathol 2011;20:155-62.

12. Fathi WK. The effect of hyaluronic acid and platelet-rich plasma on soft tissue wound healing: An experimental study on rabbits. Al-Rafidain Dent J 2012;12:115-25.

13. AL-Bayati AH, Al-Asadi RN, Mahdi AK, Al-Falahi NH. Effects of autologous platelets rich plasma on full-thickness cutaneous wounds healing in goats. Int J Anim Vet Adv 2013;5:233-9.

14. Del Corso M, Toffler M, Ehrenfest DM. Use of autologous leukocyte and platelet-rich fibrin (L-PRF) membrane in post-avulsion sites. J Implant Adv Clin Dent 2010;1:27-35.

15. Dohan Ehrenfest DM, de Peppo GM, Doglioli P, Sammartino G. Slow release of growth factors and thrombospondin-1 in choukroun's platelet-rich fibrin (PRF): A gold standard to achieve for all surgical platelet concentrates technologies. Growth Factors 2009;27:63-9.

16. Dorothy M, Adcock MD, Kressin DC, Ehrenfest L, Richard A, Marlar RA. Effect of $3.2 \%$ vs 3.8\% sodium citrate concentration on routine coagulation testing. Am J Commun Psychol 1997;107:105-10.

17. Perazzi A, Busetto R, Martinello T, Drigo M, Pasotto D, Cian F, et al. Description of a double centrifugation tube method for concentrating canine platelets. BMC Vet Res 2013;9:146.

18. Dohan DM, Choukroun J, Diss A, Dohan SL. Platelet-rich fibrin (PRF): A second-generation platelet concentrate. Part I: Technological concepts and evolution. Oral Surg Oral Med Oral Pathol Oral Radiol Endod 2006;101:37-44.

19. Naik B, Karunakar P, Jayadev M, Marshal VR. Role of platelet rich fibrin in wound healing: A critical review. J Conserv Dent 2013;16:284-93.

20. Ivany JM, Muir WW. Farm animal anesthesia. In: Fubini SL, Dusharme NG, editor. Farm Animal Surgery. St. Louis (MO): Saunders Company; 2004. p. 97-112.

21. Izadi K, Ganchi P. Chronic wounds. Clin Plast Surg 2005;32:209-22.

22. Fonder MA, Lazarus GS, Cowan DA, Aronson-Cook B, Kohli AR, Mamelak AJ, et al. Treating the chronic wound: A practical approach to the care of nonhealing wounds and wound care dressings. J Am Acad Dermatol 2008;58:185-206.

23. Reghini MF, Bussiere MC, Neto RC, Castro-Chaves MM, Resende HL, Fioratti E, et al. Effect of use of platelet rich plasma on post-breading uterine inflammatory response of mares. J Equine Vet Sci Wildomar 2014;34:127.

24. Anitua E, Andia I, Ardanza B, Nurden P, Nurden AT. Autologous platelets as source of proteins for healing and tissue regeneration. J Thromb Haem 2004;10:4-15.

25. Foster TE, Puskas BL, Mandelbaum BR, Gerhardt MB, Rodeo SA. Platelet-rich plasma: From basic science to clinical applications. Am J Sports Med 2009;37:2259-72.

26. Ferdousy RN, Rahman M, Paul S, Khan AH. Role of platelet rich plasma gel in the wound healing of black Bengal goat. IOSR J Agric Vet Sci 2013;6:14-21.

27. Alishahi MK, Kazemi D, Mohajeri D, Mofidpoor H, Goli AA, Alishahi MK. Histopathological evaluation of the effect of plateletrich fibrin on canine cutaneous incisional wound healing Iran. J Vet Sci Technol 2013;5:19-32

28. Kimura A, Ogata H, Nakajima T, Yazawa M, Watanabe N, Mori T. The effects of platelet-rich plasma on cutaneous incisional wound healing in rats. J Dermatol Sci 2005;40:205-8

29. Farghali HA, AbdElKader NA, Khattab MS, AbuBakr HO. Evaluation of subcutaneous infiltration of autologous platelet-rich plasma on skinwound healing in dogs. Biosci Rep 2017;37.

30. Moradi O, Ghamsari SM, Dehghan MM, Sedaghat R, Akbarein H. Effects of platelet rich plasma (PRP) and platelet rich growth factor (PRGF) on the wound healing of distal part of limbs in horses I. J Vet Surg 2013;8:41-8

31. Ayman F, Hosam ES, Mubarak AS. Evaluation of the clinical and histopathological effect of Platelet rich plasma on chronic wound healing. Int Res J Basic Clin Stud 2014;2:55-61. 